\title{
Enhanced Antibacterial Property by the Synergetic Effect of TiO2 and ZnO Nano-Particles in Biodegradable Hydrogel
}

\author{
Fatma Ozge Gokmen, PhD \\ Sinan Temel, PhD \\ Elif Yaman, PhD \\ Bilecik Şeyh Edebali University, \\ Central Research Laboratory, Bilecik, Turkey
}

Doi:10.19044/esj.2019.v15n33p13～URL:http://dx.doi.org/10.19044/esj.2019.v15n33p13

\begin{abstract}
In this study, three types of nanocomposite hydrogel were produced by free radical polymerization and chemical bath deposition technique together. $\mathrm{TiO} 2$ nanoparticles (NPs) have been incorporated in polymeric matrices in order to provide antimicrobial activity to the biodegradable hydrogel. Then, $\mathrm{ZnO}$ NPs have been deposited on the surface of the hydrogel to improve antibacterial activity. Structural and antibacterial properties of above nanocomposites were fully determined by X-Ray diffractometer (XRD), Fourier Transform Infrared Spectroscopy (FTIR), Field Emission Scanning Electron Microscopy (FESEM), Energy Dispersive X-Ray Spectrometer (EDX), and ASTME-2149 methods. At the reaction time of 60 minutes, nano$\mathrm{ZnO}$ particles on hydrogel were fully developed. $\mathrm{Zn}$ content of hydrogel was 35.89 at. $\%$, Ti content of hydrogel was also determined as 0.16 at.\%. In respect to antibacterial activity tests results, Escherichia coli were more resistant to hydrogel and $\mathrm{ZnO}$ nanoflower than Staphylococcus aureus.
\end{abstract}

Keywords: Antibacterial activity, Nano-TiO2, Nano-ZnO, Hydrogel

\section{Introduction}

Bacteria cause infections which result in important health problem for millions of people (Shuai et al., 2017). The principle way to kill bacteria is using antibiotics. But, some bacteria can gain the resistant to commonly used antibiotics and restrict the antibiotic treatments for infectious diseases efficiencies (Hede, 2014). Nowadays, antibiotic resistance is a significant problem for public health. For this reason, new effective antibacterial material development is necessary (Teymourinia et al., 2019). 
The interest is increasing within improving antibacterial polymers as antimicrobial agents for the applications in biomedical, food packaging and surgical device sterilizing area (Athanasoulia et al., 2018). Antibacterial polymers can inhibit bacteria growth, further they can kill bacteria (Wahid et al., 2019). Hydrogels are three dimensional (3D) polymers which made of both natural and synthetic materials dominating high number of flexibility. Superior swelling property of hydrogels makes them an ideal material for variable applications. Some characteristic properties of hydrogels can be listed as desired functionality, reusability, reversibility, sterilizability and biocompatibility (Ullah et al., 2015; Khan et al., 2013).

Antibacterial property of hydrogels can be enhanced with metal and metal oxide nanoparticles (NPs). Polymer matrices acts a substrate for active antimicrobial nanoparticles. Compared to other used materials, NPs have some superior characteristics such as small particle size, higher specific surface area to volume ratio and large proportion of surface atoms (Liu et al., 2018). $\mathrm{TiO}_{2}$ is one of the promising NPs due to its unique properties like wellstability, self-cleaning, environmental-friendly and the most important property is antibacterial capability (Athanasoulia et al., 2018). When the energy supplied higher than the band gap of $\mathrm{TiO}_{2}$, the electron $\left(\mathrm{e}^{-}\right)$/hole $(\mathrm{h}+)$ pairs are formed and react with $\mathrm{O}_{2}$ and $\mathrm{H}_{2} \mathrm{O}$ to form superoxide anion radicals $\left(\mathrm{O}_{2} \cdot-\right)$ and hydroxyl radicals $(\cdot \mathrm{OH}) . \mathrm{h}+, \mathrm{O}_{2} \cdot$ and $\cdot \mathrm{OH}$ species are highly reactive and they provide the disruption of bacteria cell. In addition to this, $\mathrm{TiO}_{2}$ has some disadvantages as biocidal agent due to its large bandgap energy and fast recombination rate of photogenerated electron-hole pairs (Hwang et al., 2011). Therefore, various nano-materials with different antibacterial property can be added to $\mathrm{TiO}_{2}$ doped materials to enhanced its antibacterial property (Jia et al., 2019). Due to its high specific surface area, excellent hydrophobicity and oxidizing ability, $\mathrm{ZnO}$ has been widely used to inhibit the growth of microorganisms. Reducing $\mathrm{ZnO}$ particles to nanoscale provides them ability to kill bacteria rapidly (Liu et al., 2019).

In this case, using of both $\mathrm{TiO}_{2}$ and $\mathrm{ZnO}$ NPs in polymeric substrates should be improved to enhance antibacterial property. However, there are no reports for production of hydrogel with $\mathrm{TiO}_{2}-\mathrm{NPs}$ and $\mathrm{ZnO}$ deposition on this hydrogel for antibacterial applications. In this study, a novel and high efficient antibacterial nanocomposite was synthesized. Firstly, nano- $\mathrm{TiO}_{2}$ doped hydrogel was produced and then $\mathrm{ZnO}$ nano-flowers were grown on the hydrogel to enhance the antibacterial property of nanocomposite material.

\section{Materials and Methods}

The chemicals used in this study are described in this section. The techniques used for preparation and characterization of nanocomposite hydrogels were also detailed in this section. 


\section{Materials}

Ammonium persulfate $(\geq 98 \%), \quad N, N^{\prime}$-methylenebis(acrylamide) (99\%), Titanium(IV) oxide ( $<100 \mathrm{~nm}, 99.99 \%)$, Zinc nitrate hexahydrate $(98 \%)$ and ammonia (>99.95\%) were purchased from Sigma-Aldrich (USA). The deionized water was used in all experiments.

\section{Synthesis of Hydrogels}

In the first part of the study, acrylic acid (AA) hydrogels were synthesized by free radical polymerization technique using with a radicalic initiator (ammonium persulfate) and a crosslinking agent ( $N, N^{\prime}$ methylenebis(acrylamide)). $\mathrm{TiO}_{2} \mathrm{NPs}$ were used as a dopant to produce $1 \mathrm{wt} . \%$ $\mathrm{TiO}_{2}$ doped hydrogel. Experimental details were given in previous study (Temel et al., 2018). Pure and $\mathrm{TiO}_{2}$ doped hydrogel was labelled as $\mathrm{H}$ and $\mathrm{TH}$, respectively.

\section{Synthesis of ZnO NPs on Hydrogels}

In the second part of the study $\mathrm{ZnO} \mathrm{NPs}$ on $\mathrm{TH}$ were deposited by chemical bath deposition technique (CBD) at different deposition times (1530-45 and $60 \mathrm{~min}$ ) as given in detail in previous study (Temel et al., 2019). ZnO NPs deposited TH was labelled ZTH.

\section{Characterization}

The X-ray diffractometry of ZTH was conducted by using XRD instrument (Panalytical, Empyrean) using $\mathrm{CuK} \alpha(\lambda=1.5405 \dot{\mathrm{A}})$ radiation at $40 \mathrm{kV}$ with $2 \theta$ ranging from $20^{\circ}$ to $80^{\circ}$ and a scanning rate of $2 \% \mathrm{~min}$.

Attenuated Total Reflectance Fourier Transform (ATR-FTIR) spectra of $\mathrm{H}, \mathrm{TH}$ and $\mathrm{ZTH}$ were obtained by using a Perkin Elmer Spectrum 100 spectrometer in the wave number ranging from 4000 to $380 \mathrm{~cm}^{-1}$, at a resolution of $4 \mathrm{~cm}^{-1}$.

Field Emission Scanning Electron Microscopy (FESEM) micrographs of $\mathrm{H}, \mathrm{TH}$ and ZTH were achieved by using a ZEISS SUPRA $40 \mathrm{VP}$ microscope. All samples were sputter coated with gold/palladium. The content of carbon, oxygen, titanium and zinc in $\mathrm{H}, \mathrm{TH}$ and $\mathrm{ZTH}$ were determined by using Energy Dispersive X-Ray Spectrometer (EDX).

\section{Antibacterial Activity Tests}

The antibacterial activity tests were carried out in accordance with ASTME2149 (Determining the Antimicrobial Activity of Antimicrobial Agents Under Dynamic Contact Conditions) with the bacteria Staphylococcus aureus (S. aureus) ATCC 6538 and Escherichia coli (E. Coli) ATCC 8739. 


\section{Results and Discussion}

In this section, results from the characterization of $\mathrm{H}, \mathrm{TH}$ and $\mathrm{ZTH}$ and their antibacterial properties were presented and discussed.

\section{Characterization of $\mathrm{H}$, TH and ZTH:}

XRD spectrum of H, TH and ZTH were given in Figure 1. The XRD pattern of $\mathrm{H}$ and $\mathrm{TH}$ showed a broad peak, which was proved with its amorphous feature and, intense and sharp peaks shown in the XRD pattern of $\mathrm{ZTH}$ demonstrate the crystalline characteristic of $\mathrm{ZnO}$. The XRD diffraction pattern of the ZTH has matched with that of the hexagonal structured $\mathrm{ZnO}$ (ICDD data: 98-003-1052) and it has polycrystalline structure (Temel et al., 2017).

In Figure 2, FTIR spectrum of H, TH and ZTH were demonstrated. Characteristic peaks which belongs to acrylic acid were located at $2942 \mathrm{~cm}^{-1}$, $1693 \mathrm{~cm}^{-1}(\mathrm{C}=\mathrm{O}), 1452 \mathrm{~cm}^{-1}(\mathrm{C}-\mathrm{OH}), 1161 \mathrm{~cm}^{-1}(\mathrm{C}-\mathrm{O})$ and $795 \mathrm{~cm}^{-1}$ in FTIR spectra of $\mathrm{H}$ [11]. In the $\mathrm{TiO}_{2}$ doped hydrogels, the $\mathrm{C}=\mathrm{O}$ vibration intensity was decreased. Similar bending was also observed at the vibration peak of the $\mathrm{C}-\mathrm{O}$ bond at $1161 \mathrm{~cm}^{-1}$. In the spectra of TH, the sharp peak at $720 \mathrm{~cm}^{-1}$ shows the bending vibration of Ti-O-Ti. The bending vibration was seen at $1638 \mathrm{~cm}^{-}$ ${ }^{1}$ as the short-sharp peak of Ti-OH bond.

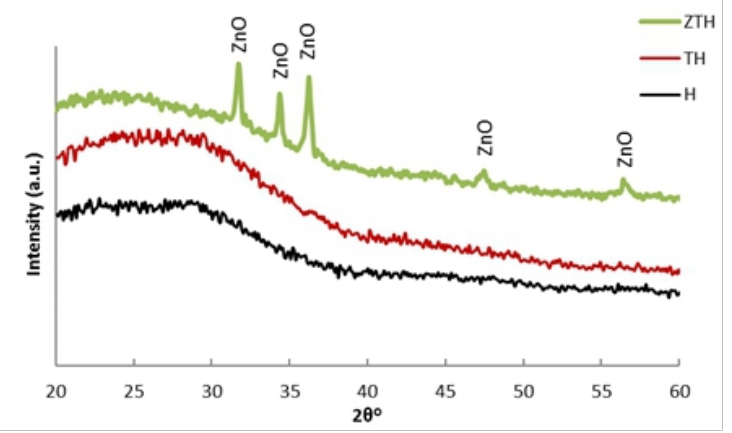

Figure 1. XRD Spectrum of $\mathrm{H}$, TH and ZTH

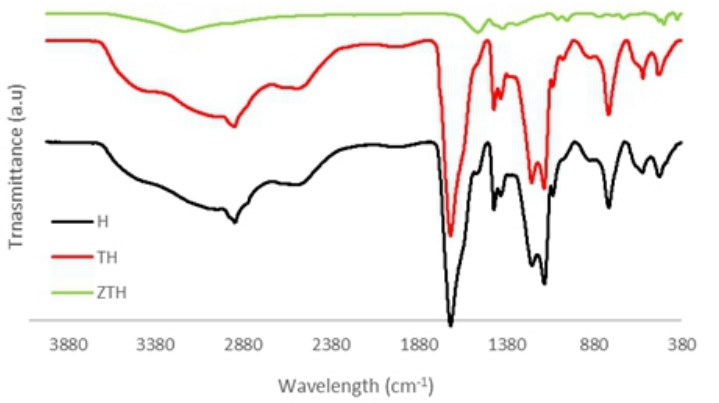

Figure 2. FTIR Spectrum of $\mathrm{H}$, TH and ZTH 
It should also be noted, the peak around $400-900 \mathrm{~cm}^{-1}$ in $\mathrm{TiO}_{2}$ nanoparticles is related to Ti-O-Ti and Ti-O-C bond in $\mathrm{TH}$ sample. The additional peaks at $500 \mathrm{~cm}^{-1}$ could be stated to the Ti-O vibrations [10]. C-OH stretching vibrations at $1452 \mathrm{~cm}^{-1}$ is slightly shifted to $1415 \mathrm{~cm}^{-1}$ in ZTH spectra compared with $\mathrm{H}$, it could indicate that the interaction between $\mathrm{Zn}^{+2}$ and $\mathrm{OH}$. This result is in conformance with FTIR studies in literature (Dincă et al., 2018; Chen et al., 2013; Hu et al., 2011).

FESEM and EDX analyses results of $\mathrm{H}$ and $\mathrm{TH}$ were given in Figure 3 and Figure 4, respectively. While carbon content of $\mathrm{H}$ was 57.55 at.\%, oxygen content was 42.45 at.\%. When titanium was doped into the hydrogel, no significant change in oxygen and hydrogen content was observed. Titanium content of TH was also determined as 0.16 at. $\%$.

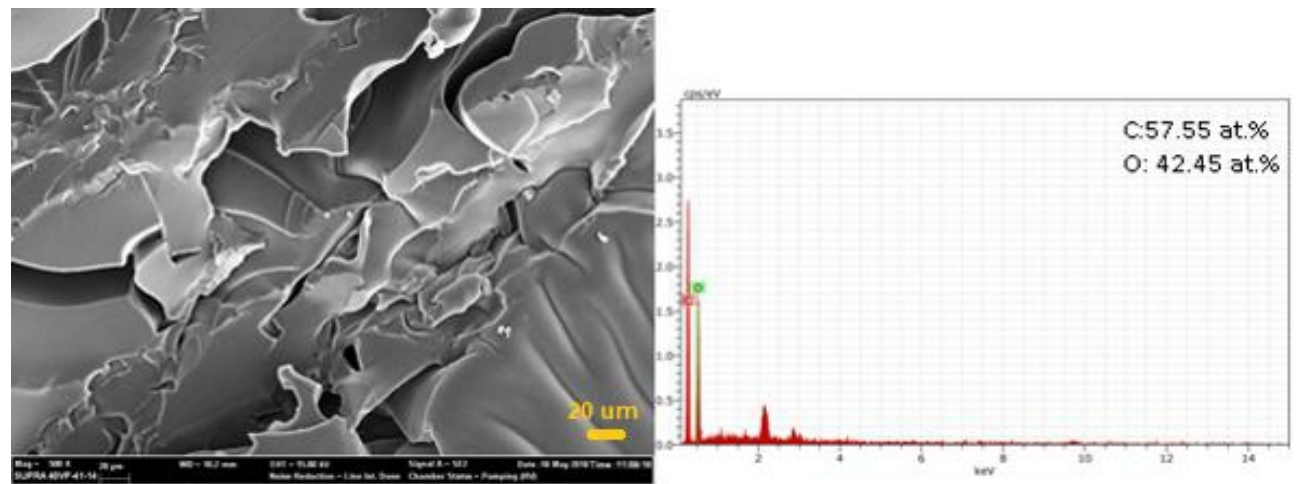

Figure 3. SEM-EDX results of $\mathrm{H}$
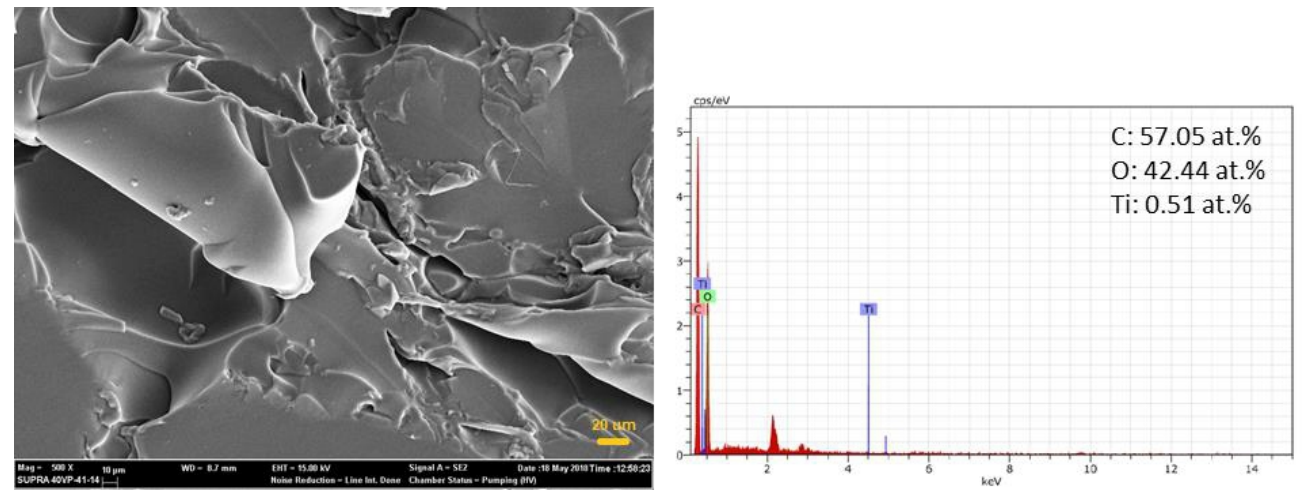

Figure 4. SEM-EDX results of TH

According to the images of nano- $\mathrm{ZnO}$ particles on hydrogel obtained using 15, 30, 45 and 60 minutes deposition time, the nano- $\mathrm{ZnO}$ structures become more apparent as the reaction time increases (Fig.5). When the deposition time of 60 minutes applied, it was observed that ZnO NPs were fully developed. EDX results of ZTH obtained at 60 min were given in Fig. 6. 
$\mathrm{Zn}$ content of hydrogel was 35.89 at.\%, Ti content of hydrogel was also determined as 0.16 at.\%.
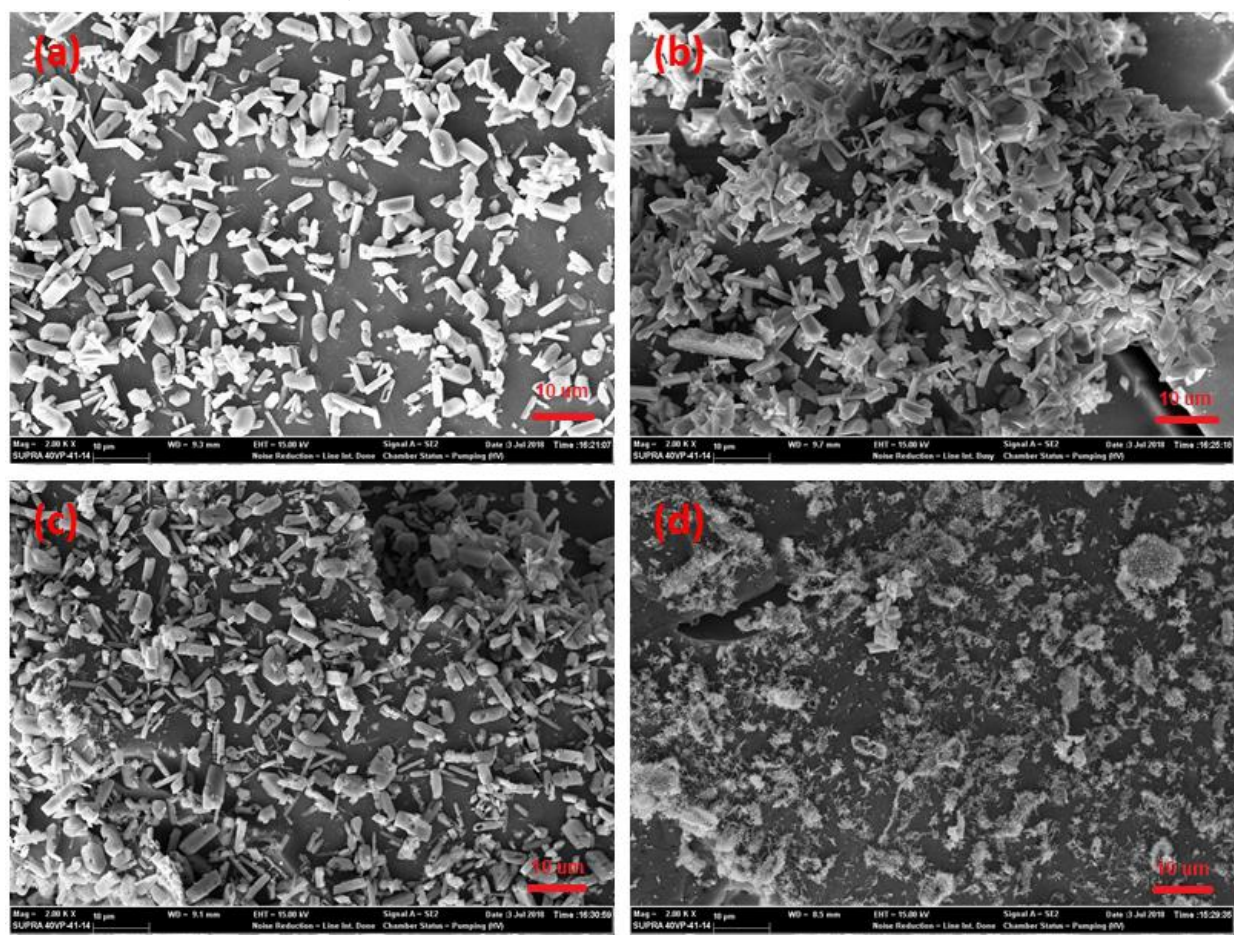

Figure 5. ZTH obtained at (a) $15 \mathrm{~min}$, (b) $30 \mathrm{~min}$, (c) $45 \mathrm{~min}$ and (d) $60 \mathrm{~min}$

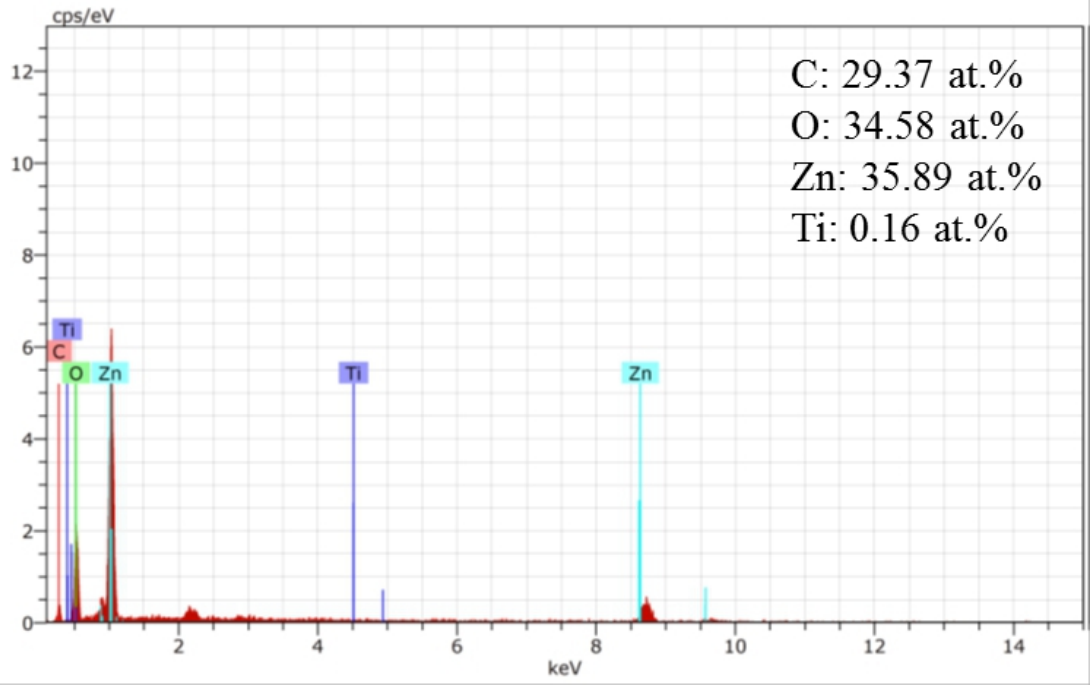

Figure 6. EDX results of ZTH obtained at $60 \mathrm{~min}$

\section{Antibacterial Activity of $\mathrm{H}$, TH and ZTH}

Antibacterial activity of $\mathrm{ZnO}$ and $\mathrm{TiO}_{2}$ has been studied for a long while and was discussed in previous studies (Teymourinia et al., 2019; 
Athanasoulia et al., 2018; Wahid et al., 2019; Jia et al., 2019). In addition to this, $\mathrm{TiO}_{2}-\mathrm{ZnO}$ composite materials have also enhanced antibacterial property (Hwang et al., 2011). In this study, antibacterial activity tests were conducted on H, TH and ZTH with gram-positive (Staphylococcus aureus) and gramnegative (Escherichia coli) bacteria. The results were given in Table 1.

Bactericidal mechanism of $\mathrm{TiO}_{2}$ and $\mathrm{ZnO}$ is still uncertain and is an important issue that should be investigated. Several bactericidal mechanisms have been suggested to specify the antibacterial property of $\mathrm{TiO} 2$ and $\mathrm{ZnO}$. The mechanisms include penetration of the cell envelope by these metal oxides and damage the cell membrane with the production of reactive oxygen species (Siwińska-Stefańska et al., 2019). Escherichia coli were more resistant to hydrogel, $\mathrm{TiO}_{2}$ and $\mathrm{ZnO}$ nanoparticles than Staphylococcus aureus. The enhanced property of antibacterial activity displayed by the synthesized composites, especially against Staphylococcus aureus, makes them promising materials for various applications.

Table 1. Antibacterial activity test results.

\begin{tabular}{|c|c|c|c|c|}
\hline Sample & Bacteria & $\begin{array}{l}\text { Count in the } \\
\text { control } \\
\text { sample after } \\
24 \text { hours }\end{array}$ & $\begin{array}{l}\text { Count in } \\
\text { sample after } \\
24 \text { hours }\end{array}$ & $\begin{array}{c}\text { Decrease } \\
(\%)\end{array}$ \\
\hline Hydrogel & $\begin{array}{c}\text { Staphylococcus } \\
\text { aureus }\end{array}$ & 530000 & 108915 & 79.45 \\
\hline $\begin{array}{c}\mathrm{Nano}^{-\mathrm{TiO}_{2}} \\
\text { doped hydrogel }\end{array}$ & $\begin{array}{c}\text { Staphylococcus } \\
\text { aureus }\end{array}$ & 530000 & 51064 & 90.37 \\
\hline $\begin{array}{c}\mathrm{ZnO} \text { nano- } \\
\text { flowers } \\
\text { deposited nano- } \\
\mathrm{TiO}_{2} \text { doped } \\
\text { hydrogel }\end{array}$ & $\begin{array}{c}\text { Staphylococcus } \\
\text { aureus }\end{array}$ & 530000 & 129 & 99.98 \\
\hline Hydrogel & Escherichia coli & 490000 & 210553 & 57.03 \\
\hline $\begin{array}{c}\text { Nano-TiO }_{2} \\
\text { doped hydrogel }\end{array}$ & Escherichia coli & 490000 & 94150 & 80.79 \\
\hline $\begin{array}{c}\mathrm{ZnO} \text { nano- } \\
\text { flowers } \\
\text { deposited nano- } \\
\mathrm{TiO}_{2} \text { doped } \\
\text { hydrogel }\end{array}$ & Escherichia coli & 490000 & 12450 & 97.46 \\
\hline
\end{tabular}

\section{Conclusion}

In this study, synthesized hydrogels were used as substrate to deposit $\mathrm{ZnO}$ NPs by chemical bath deposition technique. The simple synthesis method appears to be promising method as it is economical and environmentalfriendly manner. The synthesized composite materials were characterized by using various analytical tools such as XRD, FTIR and FESEM-EDX. According to the characterization results, deposition time plays a key role to 
obtain $\mathrm{ZnO}$ NPs. When the deposition time of 60 minutes applied, it was observed that $\mathrm{ZnO}$ NPs were fully developed. Significant differences of morphological characteristics were observed with varying deposition time. Antibacterial properties of synthesized composite materials were fully determined by applying ASTME-2149 methods. The deposited $\mathrm{TiO}_{2}$ and $\mathrm{ZnO}$ NPs on biodegradable hydrogel exhibited high activity against Escherichia coli and Staphylococcus aureus. Gram-negative bacteria (Escherichia coli) was more resistant to $\mathrm{TiO}_{2}$ and $\mathrm{ZnO}$ NPs than gram-positive bacteria (Staphylococcus aureus). It can be concluded that, the antibacterial property of hydrogel was highly depending on doping material and the hydrogel modified by $\mathrm{TiO}_{2}$ and $\mathrm{ZnO}$ have great potential for application as an inorganic antibacterial material.

Acknowledgement: The authors acknowledge the financial support provided by Scientific Research Project Commission of Bilecik Seyh Edebali University (project number is 2017-01.BŞEÜ.28-01).

\section{References:}

1. Athanasoulia, I. G., Mikropoulou, M., Karapati, S., Tarantili, P., \& Trapalis, C. (2018). Study of thermomechanical and antibacterial properties of TiO2/Poly (lactic acid) nanocomposites. Materials Today: Proceedings, 5(14), 27553-27562.

2. Chen, S., Zhou, B., Hu, W., Zhang, W., Yin, N., \& Wang, H. (2013). Polyol mediated synthesis of $\mathrm{ZnO}$ nanoparticles templated by bacterial cellulose. Carbohydrate polymers, 92(2), 1953-1959.

3. Chen, S., Quan, Y., Yu, Y. L., \& Wang, J. H. (2017). Graphene quantum dot/silver nanoparticle hybrids with oxidase activities for antibacterial application. ACS Biomaterials Science \& Engineering, 3(3), 313-321.

4. Dincă, V., Mocanu, A., Isopencu, G., Busuioc, C., Brajnicov, S., Vlad, A., \& Stoica-Guzun, A. (2018). Biocompatible pure $\mathrm{ZnO}$ nanoparticles-3D bacterial cellulose biointerfaces with antibacterial properties. Arabian Journal of Chemistry.

5. Hede, K. (2014). An infectious arms race. Nature, 509(7498 SI), S2S2.

6. Hu, W., Chen, S., Xu, Q., \& Wang, H. (2011). Solvent-free acetylation of bacterial cellulose under moderate conditions. Carbohydrate Polymers, 83(4), 1575-1581.

7. Hwang, S. H., Song, J., Jung, Y., Kweon, O. Y., Song, H., \& Jang, J. (2011). Electrospun $\mathrm{ZnO} / \mathrm{TiO} 2$ composite nanofibers as a bactericidal agent. Chemical communications, 47(32), 9164-9166. 
8. Jia, L., Huang, X., Liang, H. E., \& Tao, Q. (2019). Enhanced hydrophilic and antibacterial efficiencies by the synergetic effect $\mathrm{TiO} 2$ nanofiber and graphene oxide in cellulose acetate nanofibers. International journal of biological macromolecules, 132, 1039-1043.

9. Khan, A., Othman, M. B. H., Razak, K. A., \& Akil, H. M. (2013). Synthesis and physicochemical investigation of chitosan-PMAAbased dual-responsive hydrogels. Journal of Polymer Research, 20(10), 273.

10. Liu, J., Wang, Y., Ma, J., Peng, Y., \& Wang, A. (2018). A review on bidirectional analogies between the photocatalysis and antibacterial properties of ZnO. Journal of Alloys and Compounds.

11. Siwińska-Stefańska, K., Kubiak, A., Piasecki, A., Dobrowolska, A., Czaczyk, K., Motylenko, M., \& Jesionowski, T. (2019). Hydrothermal synthesis of multifunctional $\mathrm{TiO}_{2}-\mathrm{ZnO}$ oxide systems with desired antibacterial and photocatalytic properties. Applied Surface Science, 463, 791-801.

12. Temel, S., Gökmen, F. Ö., \& Yaman, E. (2017). Effects of Deposition Time on Structural and Morphological Properties of Synthesized ZnO Nanoflowers Without Using Complexing Agent. European Scientific Journal, 9(13), 27.

13. Temel, S., Yaman, E., \& Gökmen, F. Ö. (2018). Synthesis and characterization of $\mathrm{TiO} 2$ co-polymeric hydrogel. In AIP Conference Proceedings (Vol. 2042, No. 1, p. 030001). AIP Publishing.

14. Temel, S., Gökmen, F. Ö., \& Yaman, E. (2019). An Energy Efficient Way to Produce Zinc-Based Semiconductor Thin Films via Chemical Bath Deposition Technique. Journal of Sustainable Development of Energy, Water and Environment Systems, 7(2), 253-260.

15. Teymourinia, H., Salavati-Niasari, M., Amiri, O., \& Yazdian, F. (2019). Application of green synthesized TiO2/Sb2S3/GQDs nanocomposite as high efficient antibacterial agent against $E$. coli and Staphylococcus aureus. Materials Science and Engineering: C, 99, 296-303.

16. Ullah, F., Othman, M. B. H., Javed, F., Ahmad, Z., \& Akil, H. M. (2015). Classification, processing and application of hydrogels: A review. Materials Science and Engineering: C, 57, 414-433.

17. Wahid, F., Duan, Y. X., Hu, X. H., Chu, L. Q., Jia, S. R., Cui, J. D., \& Zhong, C. (2019). A facile construction of bacterial cellulose/ $\mathrm{ZnO}$ nanocomposite films and their photocatalytic and antibacterial properties. International journal of biological macromolecules, 132, 692-700. 